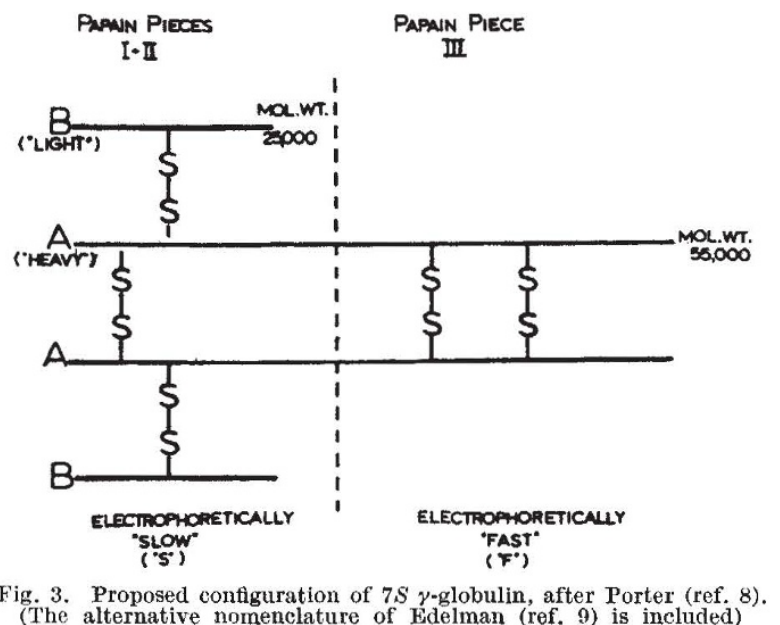

formation of visible precipitate on interaction with rheumatoid factor. Heat treatment of the $B$ chain preparation failed, however, to induce precipitability on subsequent testing with the rheumatoid arthritis serum.

These investigations, which are being extended to include the measurement of any tertiary structural peculiarities of reactive $7 S \gamma$-globulin preparations, will be reported in detail elsewhere. At the moment, all evidence points to precipitation reactivity with rheumatoid factor being located in that part of the $7 S \gamma$-globulin molecule in which the 'skin attachment' and 'membrane transmission' sites $^{10}$ are also located.

We thank Dr. K. W. Walton for providing the Cohn $\gamma$-globulin preparation and Dr. C. Hawkins for obtaining the rheumatoid arthritis serum used.

C. S. Henney

D. R. STANWORTH

Department of Experimental Pathology,

University of Birmingham.

${ }^{1}$ Oikawa, T., Clin. Res., 9, 24 (1961).

${ }^{2}$ Cohen, E., Nature, 190, 552 (1961).

Franklin, E., Rep. Tenth Intern. Cong. Rheumatology, Rome (September 1961).

‘ Goodman, J., Proc. Soc. Exp. Biol. (N.Y.), 106, 822 (1961).

s Porter, R. R., Biochem. J., 73, 119 (1959).

- Epstein, W. P., Johnson, A., and Ragan, C., Proc. Soc. Exp. Biol. (N.X.), 91, 235 (1956).

'Fleischman, J. B., Pain, R. H., and Porter, R. R., Arch. Biochem., Supp. $1,174(1962)$.

- Porter, R. R., Symp. Basic Problems in Neoplastic Disease, edit. by Gellhorn, A., and Hirschberg, E. (Columbia Univ. Press, 1962).

Edelman, G. M., and Benacerraf, B., Proc. U.S. Nat. Acad. Sci., 48, 1035 (1962).

${ }^{10}$ Porter, R. R., and Press, E. M., Ann. Rev. Biochem., 31, 625 (1962).

\section{Unexpected Acute Toxicity of Aminopterin}

THIs communication records the occurrence of a somewhat unusual form of acute toxicity which was observed in the course of an experiment designed to investigate the possible carcinogenicity of aminopterin. As part of this investigation aminopterin ( $C$ grade) (California Corporation for Biochemical Research, Los Angeles) was examined in new-born mice. The mice used were Swiss from the colony of this laboratory that have been maintained here for 12 years and are randomly bred. Ten litters of newborn mice less than $16 \mathrm{~h}$ of age were treated with a single subcutaneous injection in the dorsal region of $10 \mu \mathrm{g}$ of aminopterin dissolved in $0.05 \mathrm{ml}$. of distilled water (with 4 drops of 10 per cent potassium hydroxide added to each $5 \mathrm{ml}$. of the standard solution). The mice were distributed. in 9 litters of 8 new-born animals each and 1 of 7 new-born. They were housed in plastic cages on sterilized granular cellulose bedding with the mothers.

On the third and fourth days following injection the mothers, which had not been injected, died in 6 of the
10 cages. The injected new-born mice, on the other hand, still survived. In the other 4 cages some of the siblings died prior to their mothers' death although cannibalism made a precise evaluation difficult. At autopsy no gross pathological change was observed in the mothers; how ever, histological study revealed profound bone marrow destruction.

In view of the surprising nature of these findings the experiments were repeated twice and gave identical results. Many other experiments have been undertaken in this laboratory on the effects of chemical compounds on new born rodents, most of them with polycyclic hydrocarbons $^{1-7}$. In no instance has any effect similar to this been observed. In the instance of polycyclic hydrocarbon carcinogens it has been found that the new-born is more sensitive than the adult in the production of lymphoma 4 which has recently been found to be associated with a delayed metabolism of the carcinogen 9,10-dimethyl-1,2. benzanthracen ${ }^{8}$.

It is known that the contraction and emptying of the urinary bladder in young rats and puppies are regulated by stimulation from the mother's tongue in the perineal area until the animals are 16 days of age $\theta^{9-12}$. It is apparent that the mothers may ingest much of the urine, since it has recently been demonstrated that iodine-131 administered to sibling rats separated from their mothers and then re-united could be recovered in a matter of $4 \mathrm{~h}$ after reunification ${ }^{13}$.

From the work recorded here it appears clear, first, that the aminopterin entered into the circulation of the untreated mothers from their treated siblings in some not clearly visible way; secondly, it appears that adult mice are more sensitive to the acute toxic effects of aminopterin than the new-borns. This later phenomenon might be due to various factors; since it is known that new-born animals have low levels of certain enzymes ${ }^{14}$, a reasonable explanation of this observation is that there may be a reduced level of folic acid reductase for which aminopterin has a powerful affinity ${ }^{15}$. If this were so, the new-born animals would excrete unchanged aminopterin, rapidly resulting in the lethal effect observed in the mothers.

This work was supported by the U.S. Public Health Service grant $C S-9212$.

BeLA TOTH

Philippe Shubik

Division of Oncology.

Chicago Medical School, Chicago 12.

'Pietra, G., Spencer, K., and Shubik, P., Nature, 183, 1689 (1959).

'Pietra, G., Rappaport, H., and Shubik, P., Cancer, 14, 308 (1961).

${ }^{3}$ Toth, B., Rappaport, H., and Shubik, P., Proc. Soc. Exp. Biol. Med.,110 881 (1962).

"Toth, B., Rappaport, H., and Shubik, P., J. Nat. Cancer Inst., 30, 723 (1963).

${ }^{3}$ Rappaport, H., and Baroni, C., Cancer Res., 22, 1067 (1962)

- Toth, B., and Shubik, P., Brit. J. Cancer (in the press).

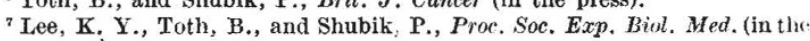
press).

Domsky, I. I., Lilinsky, W.. Spencer, K., aud Shubik, P., Proc, Soc. Exp. Biol. Med., 113, 110 (1963).

- Heller, H,, J. Physiol., 108, 245 (1947).

${ }^{10}$ McCance, and Wilkinson, E., J. Physiol., 106, 256 (1947).

${ }_{11}$ Capek, K., and Jelinek, J., Physiol. Bohemoslow., 5, 91 (1956).

${ }^{13}$ Capek, K., and Jelínek, J., Physiol. Bohemoslov., 5, 97 (1956).

${ }^{13}$ Samel, M., Čaputa, A., and Struhárová, L., Nature, 198, 489 (1963)

${ }^{14}$ Isselbacher, K. J., Science, 126, 652 (1957).

${ }^{15}$ Bertino, J. R., Cancer Res., 23, 1286 (1963).

\section{Changes in Epithelial Cell Lysosomes during Experimental Oral Carcinogenesis}

THF general concept of lysosomes as separate cytoplasmic organelles was originated by de Duve ${ }^{1}$ in 1955 , when he also demonstrated that acid phosphatase is characteristically present in these structures. Other workers $^{2,3}$ have determined the cytological location of lysosomes by applying histochemical techniques for acid 